\title{
DEVELOPMENT OF FREIGHT TRANSPORT IN THE EUROPEAN UNION - SELECTED ISSUES
}

\author{
Józef Marian BENDKOWSKI ${ }^{1}$, Jacek Maria BENDKOWSKI ${ }^{2 *}$ \\ ${ }^{1}$ Silesian University of Technology, Faculty of Organization and Management, Institute of Management, \\ Administration and Logistics; Jozef.Bendkowski@polsl.pl, ORCID: 0000-0002-5165-5109 \\ ${ }^{2}$ AWF Katowice, Wydział Zarządzania Sportem i Turystyką, Katedra Teorii Zarządzania; \\ J.Bendkowski@awf.katowice.pl, ORCID:0000-0002-8711-1728 \\ * Correspondence author
}

Purpose: This article discusses the current trends in transport in the European Union, paying special attention to the plan to create a single European transport area, striving to achieve a competitive and resource-efficient transport system.

Design/methodology/approach: Using the methods of literature analysis and document analysis, the assumptions of the common transport policy, sustainable development of European transport, applicable legal regulations were analyzed. White Paper on transport in the European Union.

Findings: It was agreed that a single European transport area should facilitate the movement of citizens and goods, reduce its costs and ensure the sustainable development of European transport, the main directions of transport policy include revitalization of the railway sector.

Research limitations/implications: It has been shown that focusing on the following problems: increasing the competitiveness of railways, including modern technologies in the transport system, introducing a port policy, producing more biofuels, reducing urban traffic and introducing charges for the use of infrastructure are factors for achieving the competitiveness of the European transport system.

Practical implications: The practical implications of the presented and analyzed issues are related to IT support for transport, logistics companies, internet technology, internet exchanges and support for IT systems of railway carriers. Trends in the transport of general cargo, road and bulk materials occurring in the EU were pointed out. Advantages and disadvantages of general cargo in transport were pointed out.

Social implications: This article considers original that transport enables economic growth and job creation. The development of transport must be sustainable. As a global sector, effective action in this area requires close international cooperation. The Single European Transport Area should facilitate the movement of citizens and goods, reduce its costs and ensure the sustainable development of European transport.

Originality/value: The article is addressed primarily to logistics and transport organizers.

Keywords: transport, transport policy, logistics companies, White Paper on transport, freight transport. 


\section{Introduction}

Transport is the basis for the development of any country's economy. The free movement of goods is one of the essential components of the EU's internal market and is crucial to maintaining the competitiveness of European industry and services. It has a significant impact on economic growth and job creation. Inland freight transport volumes in the EU (including road, rail and inland waterways) have stabilised at around 2300 billion tonne-kilometres per year in recent years, with a share of around $75 \%$ for road transport.

On the other hand, transport has a negative impact on the environment and on the quality of life of EU citizens. It accounts for about one third of the EU's energy consumption and total $\mathrm{CO}_{2}$ emissions. Promoting efficient and sustainable transport modes, such as rail and inland waterway transport, at the expense of road transport could help reduce Europe's dependence on imported oil and reduce pollution. According to data from the European Environment Agency (Environmental indicator...), the level of carbon dioxide emissions per tonne-kilometre for rail freight transport is 3.5 times lower than for road transport.

More sustainable transport modes could also contribute to reducing congestion costs, which, according to current estimates, are expected to increase by $50 \%$ by 2050 to almost $€ 200$ billion per year. In addition, they could help to reduce the number of road traffic casualties.

The EU policy objectives of reducing road freight transport by rail have been translated into a series of EU legislative measures to open up the market, ensure non-discriminatory access and promote interoperability and safety. Between 2007 and 2013, the EU budget contributed around $€ 28$ billion to projects in the rail sector.

The aim of the article, according to its title, is to present the main trends of transport policy in the European Union. It was considered logical, from the logistics point of view, to also present selected transport issues and challenges.

\section{Transport in logistic systems - selected issues}

\subsection{Costs of operating the transport system}

Transport costs are an element that is not only examined by logisticians. Transport costs (Mendyk, 2009) are affected with:

- sales costs (customer service, storage of finished goods, trading risk, capital freezing),

- shipping costs (packaging, sorting, marking, fees and customs activities, loading),

- costs of storage in units of trade,

- freight transport costs (including the costs of using transport equipment),

- costs of customer service in retail outlets (costs of maintaining the retail network). 
And the transport costs depend on:

- the volume of trade in goods,

- the characteristics of the goods which determine their transportability and storage,

- capacity,

- the spatial location of the participants undertaking exchange,

- the adopted technology and organisation of storage, handling and securing of cargo.

A systemic analysis of the economic phenomenon is the basis for the development of a specific logistics concept. The functioning of the system requires not only a description, characteristics of individual elements of the system, but also identification of their connection and relationships among particular elements.

The transport is linked to:

- warehouse management,

- storage keeping,

- transport of materials, components and finished products,

- the location and operation of supply and distribution centres,

- availability and use of transport means,

- appropriate transport technology,

- the unitisation of loads,

- organisation and management of transport processes.

Global logistics costs of transport systems are generated by each of the subsystems, but also by the relationships between these subsystems.

The total (global) cost structure of the selected transport system includes:

- costs associated with maintaining supplies,

- transport costs,

- random costs,

- costs of functioning of warehouse infrastructure,

- costs of packaging management,

- costs of waste storage,

- costs of order processing.

One of the basic economic issues is the problem of making optimal decisions. In logistics theory the idea of optimal management of resources and processes is connected with the idea of trade-off. It is difficult to translate this phrase into Polish, but it corresponds to the term "something for something". Simply put, it is about finding the best solutions from the point of view of the whole. Connections occurring in logistics, transport or production systems very often cause the so-called "cost conflicts", which means that improvement in one part of the system may be associated with deterioration in another. However, if this is advantageous to the system as a whole, then it is beneficial. In terms of costs, this means that a reduction in the operating costs of one element of the system may result in an increase in the costs of another 
element, e.g. worse usage of the existing potential, greater workload, increased costs of acquiring the necessary resources.

In freight transport (Mendyk, 2009), the following indicators are of help in decision making. Namely:

- Transportability of cargo,

- Storage susceptibility of the goods.

Transport susceptibility - resistance of the cargo to conditions and effects of displacement. It can be distinguished:

- natural susceptibility (physical, biological, chemical properties),

- technical susceptibility (mass, shape, volume),

- economic susceptibility (related to the value of the transported cargo; the higher the value of the cargo, the less economic usefulness. It is the ratio of transport costs to the value of the cargo expressed in its price).

Storage susceptibility - resistance of goods to storage conditions and duration of storage. It can be distinguished:

- cargo not susceptible to storage (up to 24 hours),

- medium-susceptible loads (up to 1 month),

- loads susceptible to storage (over 1 month).

The adoption of a specific logistics concept is preceded by an analysis of make or buy decisions (which is decisive), i.e:

- Financial, organisational and human resources capabilities,

- Availability of logistics services on the market.

\subsection{Use of specialised logistics service providers}

The company has a choice of two courses (Ciesielski, 2006) of action:

- use of logistics services of several entities (then the implementation of the logistics concept is fragmented),

- purchase of own freight rolling stock (advantages: improvement and optimisation of transport and lower costs generated, greater control and flexibility of service in external and internal transport; a driver may also perform other functions, e.g. salesman; reduction of stock levels in the company and with contractors, an advertisement may be placed; disadvantages: employment of appropriate service specialists, adequate amount of financial resources, significant increase of fixed costs).

The scope of the use of own transport should be determined on the basis of the criteria of regularity and relative stability of transport needs, both in terms of supply and in terms of sales and distribution. 
According to these criteria, transport needs can be divided into:

1. regular needs in stable business relations,

2. regular needs in changing business relations,

3. non-regular needs in regular business relations,

4. non-regular needs in changing business relations.

Actions related to transport (a specialised entity) (Mendyk, 2009) should concern:

1. controlling the supply of purchased goods,

2. taking the material from the manufacturing sites and their suppliers to the current sites of manufacturing,

3. quantitative and qualitative controlling,

4. conducting warehouse management, disposing of stocks of raw materials and finished goods,

5. distributing of finished goods according to customers' wishes,

6. delivering of prepared assortment batches to buyers,

7. organising customs clearance,

8. performing actions in the form of invoicing and complaints,

9. providing of consulting services.

The communication system between the ordering party and the contractor must ensure:

- adaptation of the size and structure of transport and storage capacity to changing transport and storage needs,

- exchange of information on the progress of movement processes, shipment location and condition, delays and obstacles to the exchange process, comparative analysis of costs of all activities,

- obtaining information on the course of the exchange process, on the basis of which it is possible to formulate actions in the sphere of production allowing for the reduction of production costs.

We can distinguish two general approaches of enterprises in the market characterised by:

- Passive actions of enterprises on the market.

Without technical changes, they introduce new solutions, e.g. a new form of acquisition.

- Active actions.

The idea of closer integration within transport and the integration of service production and information exchange are subject to action. The basis for this is a change in the level of competition. They do not compete as individual producers of substitutes but rather as complementary (complementary entities). 
The literature (Sikorski, Zembrzycki) discusses the following groups of services in transport companies:

- transport services based on the direct movement of objects of transport by carriers from the point of consignment to the point of destination,

- transport services which include transhipment, warehousing, solving packaging problems, completing shipments,

- services provided in the form of consultancy, mediation and organisation of transport and transport services.

The behaviour of recipients of services is characterised by:

- a liquid form: where you begin by offering one service and then expand it to the others.

- a jumping form: the framework project for the provision of services is discussed in detail during negotiation phase.

The success of logistics services in the transport market is determined by:

- ability to manage the labour distribution,

- ability to select partners fulfilling the role of subcontractors providing services complementary to services performed on their own,

- ability to negotiate rules and service levels with clients for a service rendered,

- ability to use the customer's concept and to innovate in the exchange process in accordance with this concept.

Nowadays, freight transport is characterised by:

- Multimodal transport - transport of goods through at least two different modes of transport.

- Intermodal transport - transport of goods in one and the same transport unit or vehicle using successively different modes of transport in changing modes of transport.

- Combined transport - a particular form of intermodal transport where the main part of the transport is carried out by rail, inland waterway or sea and each carriage is delivered by road over the shortest possible distances.

Multimodal transport operator - a person undertaking the execution or responsibility for the execution of the entire delivery route, from the place of receipt of goods to the designated place of their release, issuing at the same time a document covering the entire route of transport.

The transport chain - a rational succession of transport, handling and storage processes, coordinated from the technical, technological, organisational and commercial point of view, aimed at moving material goods necessary for the functioning of the national economy in space and time. 
The TFL market (Transport - Forwarding - Logistics) in Poland offers (Sikorski, Zembrzycki):

- transport services (freight transport),

- forwarding services (organisation of transport, insurance, preparation of documentation, customs service),

- logistics services - forwarding services + terminal services, starting from cross-docking, through warehousing to picking and finishing operations (tagging, polonisation, re-packing, foiling).

In addition, logistics companies often manage the inventory levels of their customers, undertake comprehensive distribution services, i.e. logistics consulting. The basis for creating a logistic service is having an extensive IT network.

In the area of transport in Poland, the following strategic groups can be distinguished (Mendyk, 2009; Sikorski, Zembrzycki):

1. transport and forwarding in rail transport (bulk transport and containers),

2. specialised transport (niche group),

3. mass road transport (own rolling stock),

4. bulk road freight forwarding,

5. road transport of general cargo and bulk goods,

6. truck forwarding of break bulk cargo and logistic services.

\subsection{The concept of time competition}

The concept of time competition (Christopher, Peck, 2005) or rather time compression in an integrated supply chain was developed in the $1980 \mathrm{~s}$.

Time-based competition - a term invented by a consulting group. It has been practiced in Japan.

This strategy has developed in the production field and has been transferred to other functional areas of the company. Time-based competition has started to relate to integrated supply chains. The full use of time strategies and benefits can be applied to so-called virtual expanded companies.

The strategy of time competition is determined by:

1. social factors: development of the industrial sector, services, trade, leisure time society, time has become a luxury resource,

2. economic factors: exploitation of cheaper and simpler methods to gain competitive advantage over time. 
External conditions for the implementation of time-based competition (Ciesielski, 2006):

- exhaustion of other, simpler methods of achieving competitive advantage,

- increasing consumer pressure for high quality, affordable prices and fast delivery of offered products,

- information, production and transport facilities enabling the implementation of the postulates of the time strategy.

Time-based competition strategy is sometimes compared to that of the OODA (English pilots during World War II). It allows you to shorten the time loop of observation, orientation, decision and action.

\section{The European Union's transport policy}

\subsection{Legal regulations}

Transport is one of the pillars of the development of the economies of the Member States of the Union. The efficient functioning of transport services has a significant impact on the efficiency of management and on measurable benefits. In 2018, transport expenditure in the European Union reached EUR 1 trillion, which is more than $10 \%$ of the total gross domestic product of the European Community Member States.

The conduct of the common economic policy was first established in the Treaty of Rome (1957), in Article 3 creating the European Economic Community (Przybyłowski, 2004). This document contains a separate chapter on "Transport" referring to the common economic policy. In the current Treaty on the Functioning of the European Union, Articles 90-100 deal with this issue. The established regulations (Grzelakowski, Matczak, Przybyłowski, 2011) concern the introduction of unified rules in international transport to or from the territory of a Member State, transit, transport safety conditions for the provision of transport services in the Community by companies from outside the Union and funds for increasing the provision of logistic services.

European transport infrastructure. In 1997, the Amsterdam Treaty extended the co-decision procedure (with the participation of the European Parliament) to all transport law in the European Community.

The formal beginning of the common transport market dates back to January 1, 1993 with the establishment of a common European market. However, in practice, harmonisation of rules and liberalisation of legislation extended until the end of the 1990s. The adopted regulations have brought noticeable benefits, both in the freight and passenger transport sectors.

The best-known transport projects in the EU are the high-speed train network and the Galileo navigation satellite concept. 


\subsection{Main goals of the common transport policy}

The analysis and study of legal documents allows to define the main principles of the common transport system concept (Grzelakowski, Matczak, Przybyłowski, 2011):

1. liberalisation of the conditions for international transport between Member States,

2. increase security in all modes of transport,

3. improving the quality of transport operations by developing an integrated system of connections using the most modern technologies,

4. better protection of the environment against pollution caused by transport,

5. common labour standards and unified terms and conditions of employment for workers in the transport sector,

6. increase the economic cohesion of the European Union by creating a trans-European transport network,

7. facilitating access of Community entrepreneurs to foreign markets.

The adopted resolutions were aimed at transforming the European Union into the most dynamic and competitive area in the world by 2010. The European Commission drew up a ten-year transport action plan in 2001.

The conclusions of the mid-term review carried out in 2006 pointed to the need to focus on:

- improving the competitiveness of railways,

- the inclusion of modern technologies in the transport system,

- the introduction of a port policy,

- production of more biofuels,

- urban traffic restrictions,

- the introduction of infrastructure user charges.

\subsection{Revitalising the railway sector}

Promoting more efficient and sustainable modes of transport, especially rail freight, has been a key element of EU policy for 25 years. As early as 1992, the European Commission set as its main objective the change in the modal share of total transport. In 2001 the European Commission confirmed (Engelhardt, 2018) the importance of revitalising the rail sector and has set the objective of maintaining the rail freight market share of the Central and Eastern European Member States at $35 \%$ by 2010.

Then, in 2011, the Commission decided that by 2030 no less than $30 \%$ of road freight transport over $300 \mathrm{~km}$ should be shifted to other modes of transport (such as rail or inland waterways), and by 2050 no less than $50 \%$.

In the countries of the European Union there is a tendency to decrease the share of rail freight in overall transport. In 1970 the share of rail transport was $21.1 \%$, and in 1998 it decreased to the level of $8.4 \%$. In France, for example, this share was 52.6\% in 1960, while in 1995 it was only $17.4 \%$. 
The main reasons for this state (Engelhardt, 2018) are as follows:

1. low commercial speed of freight trains resulting from: simultaneously carrying out passenger and freight transport on the same lines, poor technical condition of infrastructure, historically conditioned preference of passenger transport (freight trains are often stopped in order to run trains with higher priority), difficult passage of freight trains through sections heavily burdened with rail traffic;

2. lower rates for freight transport by road than by rail due to the exclusion of external costs and full infrastructure maintenance costs from the calculation;

3. non-utilisation of heavy trains with a larger loading gauge, enabling improvement of economic efficiency of transport; the reasons for this are: currently low (22.5 t) axle load, length of station tracks not exceeding $750 \mathrm{~m}$, numerous engineering structures (road viaducts) located above railway lines;

4. low utilisation of new technologies in rail transport bringing the place of consignment forwarding and receiving closer to the potential customer (combined transport);

5. the low degree of liberalisation of rail freight transport which is likely to improve its economic efficiency.

In Poland, the main reasons for the decrease in rail freight transport (Grzywacz, Wojewódzka-Król, Rydzkowski, 2006) were the following:

- decreasing transport intensity of the economy as a result of restructuring of heavy industry and agriculture,

- increasing the competitiveness of private road transport using cheap road infrastructure,

- inadequate adaptation of the structure of freight rolling stock to market needs (lack of specialised wagons for the transport of highly processed goods),

- significant physical wear and tear on wagons and locomotives, long journey times,

- a poor offer of logistics services.

\section{White Paper - Roadmap to a Single European Transport Area}

\subsection{Reasons for the White Paper}

In the terminology of the European Union, a White Paper is a document containing officially developed, conceptual proposals relating to specific areas of EU policy and usually presents a catalogue of concrete proposals and measures for the implementation of Treaty tasks. The White Paper is often based on the Green Paper, followed by the European Commission's preparation of detailed legislative proposals.

White paper is normally a report produced by a government, institution or organisation that analyses a particular product, service, technology or program. 
It is essentially a blueprint for the creation of a Single European Transport Area aiming at a competitive and resource efficient transport system (Grzelakowski, 2003).

A strategic document with very ambitious objectives. The ultimate aim of future action is to complete the Single European Transport Area. This is to be an area where the transport sector will have a high level of competitiveness and, in addition, will make very economical use of non-renewable natural resources.

\subsection{Framework guidelines for a Single European Transport Area}

The White Paper as a European Union document, its final version, was published in Brussels on 28.3.2011.

The table of contents (Grzelakowski, 2003) includes the following chapters and subsections:

1. Preparing the European transport area for the future.

2. The vision of a competitive and sustainable transport system.

2.1. Ensure growth of the transport sector and promote mobility while at the same time achieving the $60 \%$ reduction target.

2.2. Efficient network of multimodal travel and transport between cities.

2.3. Equal opportunities worldwide for long-distance and intercontinental freight transport.

2.4. Green urban transport and commuting.

2.5. Ten targets for a competitive and resource efficient transport system: benchmarks to achieve the $60 \%$ greenhouse gas emission reduction target.

3. Strategy - what to do.

3.1. The Single European Transport Area.

3.2. Innovation for the future - technology and behaviour.

3.3. Modern infrastructure, smart charging and financing.

3.4. External dimension.

4. Conclusion.

The ultimate goal is to be achieved by 2050 and will be made possible by the following 10 specific objectives. The formulated objectives (Grzelakowski, 2003) include:

1. The reduction by half of the number of conventional cars (non-hybrid combustion engined vehicles) in cities by 2030 and the total elimination of such vehicles from urban traffic by 2050. Achievement of $\mathrm{CO}_{2}$-free city logistics in the centres of big cities by 2030 .

2. Achieve a $40 \%$ share of low-carbon fuels in aviation by 2050 . Reduce $\mathrm{CO}_{2}$ emissions from maritime liquid fuels by $40 \%$ (and potentially $50 \%$ ) by 2050 . 
3. Moving $30 \%$ of freight from road to other modes of transport i.e. rail, sea and inland waterway transport over distances of more than $300 \mathrm{~km}$ by 2030 and $50 \%$ by 2050 . This will be facilitated by the creation of efficient, green transport corridors. However, their creation requires the development of appropriate infrastructure.

4. The completion of the high-speed rail network by 2050. This is to be achieved by extending its length three times by 2030, while maintaining a dense rail network in all Member States. In addition, by 2050 , the majority of medium-distance travel should be done by rail.

5. Creation of a fully functional, multimodal core network (TEN-T) covering the whole EU by 2030 and by 2050 a high capacity and quality TEN-T network with a complementary set of relevant information services.

6. The integration of all airports (the core network) into the rail network. This should preferably be a high-speed rail network. Ensuring that all major sea ports are well connected to the rail freight network and, where possible, to the inland waterway network.

7. The implementation of the modernised air traffic management infrastructure (SESAR) by 2020 and the completion of the European Common Aviation Area implementation of adequate traffic management systems in individual transport branches (ERTMS, ITS, SSN, LRIT, RIS and Galileo) by 2020.

8. The establishment of a framework for a European information, management and payment system by 2020 .

9. Reducing the number of road fatalities to almost zero by 2050 and reducing it by half by 2020 . The EU is to become a world leader in safety and security in all modes of transport.

10. The final implementation of the 'user pays' and 'polluter pays' principle and the full involvement of the private sector to eliminate disruptions such as harmful subsidies and revenue generation in order to ensure the financing of future transport investments.

\section{Reflections on selected transport issues in the European Union}

\subsection{Trends in break bulk cargo and road transport}

Break bulk - a term used to describe all goods intended for transport in the form of small packages (Pisz, Łapunka, 2013). These are usually cardboard packages, parcels, crates, bags, sometimes additionally placed on Euro-pallets. Currently, most of the break bulk cargo is transported in containers over longer distances. 
Break bulk cargo comprises both processed products and finished products with their own individual or collective packaging. They make it possible to separate from them the cargo unit to be divided. Most of the cases are small objects and special care is needed during loading, handling, transport and unloading. After collection by the forwarder, break bulk cargo loads are combined into one group load. Break bulk cargo is characterised by low unit weight and a variety of shapes and packaging. For this reason, they are usually combined into a bulk cargo whose transport cost results from the actual or calculated weight of the cargo. What distinguishes break bulk cargo are also its dispersed senders and recipients (Rydzkowski, Wojewódzka-Król, 2008).

Break bulk cargo load, as a subject of transport, is any kind of processed product and finished product which is transferred in individual or collective packaging. Such a cargo has a solid external form and a separable cargo unit which is not split during transhipment. It has different external dimensions and properties and its unit value is much greater than that of bulk cargo. Break bulk cargo requires special care during transport and transhipment. In contrast to bulk cargo, the content of a break bulk cargo consignment can be weighed and calculated. Due to their small volume, break bulk cargo is a component of groupage cargo. The individual loads of multiple shippers are collected and combined by the shipper and then shipped as a group load to individual recipients.

Break bulk cargo is divided into those with packaging, which may comprise cartons, cases, bottles, cages, barrels, bags, and those without packaging. It is worth remembering that packaging plays a very significant role here because such products are much more likely to be damaged and destroyed than other loads.

Transport of break bulk cargo is a process much more complex than in the case of bulk cargoes (Igliński, 2011). In order to increase the efficiency and effectiveness of transport, transport companies use the so-called unitisation which involves the creation of one loading unit out of several or several dozen packages. Pallets and containers are most often used for this purpose.

Break bulk cargo has certain advantages. Namely:

- adjusting the size of deliveries to the customer's needs,

- delivery on time,

- no need to store stocks of goods,

- reduction of costs related to goods storage, internal logistics etc.,

- the possibility of unitising the goods.

Packaging has certain functions:

- protects goods against harmful influence of atmospheric factors,

- protects goods against chemical influences,

- facilitates transport,

- facilitates storage, 
- it is an advertising (marketing) factor,

- helps to identify the product,

- provides information on the contents,

- enables easy and convenient forming of collective units.

The packaging should be properly labelled and marked which makes it easier to know what cargo is being transported and how to proceed during transport. It should also meet climate requirements and take into account the customs of the country to which we send the goods. Failure to properly label the packaging may result in damage or even total loss of use value of the product. That's why it's very important. These signs are usually placed on the outer side of the packaging in a clearly visible place so that everyone who takes the shipment into their hands pays special attention to them.

The marks on the packaging are divided into four groups (Korzeniowski, Skrzypek, Szyszka, 2001):

1. essential - they are used to identify the goods,

2. informational - make us familiar with the characteristics of the goods,

3. hazardous - they draw attention to the characteristics of the load that endanger people and the environment,

4. manipulative - they inform about the way of handling the cargo (Januła, Truś, Gutowska, 2011).

The Literature (Januła, Truś, Gutowska, 2011) distinguishes the following types (groups) of creating unitary collective loads.

1. Ceiling - strapping of several pieces of cargo (e.g. shovels, rakes).

2. Palletisation - placing goods on a pallet (Pallets are flat wooden platforms of specific dimensions. They may be different. The most common is the EUR pallet (800 $\mathrm{mm} \times 1200 \mathrm{~mm})$. Other types of pallets are EUR pallets and industrial pallets (1000 mm x $1200 \mathrm{~mm})$.

3. Containerisation - placing of cargo in a container.

4. Packaging - createng a package from cargo, packages (e.g. matchboxes).

During the storage and handling process, the products are exposed to the following damage:

1. physical (mechanical) - most often it occurs at the moment of improper handling of shipments (e.g. by couriers or warehouse workers). Both the packaging and the cargo contained therein may be damaged. It is however important to remember that people are not always guilty. Such damage can even be caused by the interaction of the packaging.

2. Climatic - if the packaging is not suitable for the product, the weather conditions may damage it. Rain, snow, high or low temperatures and sunshine can completely destroy goods.

3. Chemical - happens when a dangerous chemical compound gets into a shipment. 
4. Biological - occur when due to poor protection of the product, microorganisms or small animals (e.g. fungi, insects) get into the product.

5. Others - related to fire, flooding, spillage or dirt (Pisz, Łapunka, 2013).

From the logistical point of view, the transport of break bulk cargo has the following disadvantages:

- lower efficiency compared to full truck loads,

- most often the underutilisation of the loading space of the means of transport and the warehouse,

- the necessity of transporting small consignments to and from the terminal,

- the necessity to use a variety of handling equipment and equipment,

- time-consuming handling and unloading process,

- due to the small size of the consignments, they are more susceptible to damage.

In the field of logistics and forwarding, the most frequently transported loads are break bulk cargo which require the use of modern solutions ensuring their simple and efficient transport.

\subsection{Transport of loose cargo}

Loose cargoes belong to dry bulk cargo. The most common are: artificial fertilisers, cement, lime, aggregates, sand, gravel, soil, debris, coal, metal ores, fodder, flour, salt, sugar, rice and grain.

They are usually transported in bulk or packed in bags (paper, plastic, jute, linen) as well as barrels, crates and containers. They are transported by all means of transport using universal means.

Rail is a very common means of transport for loose cargo in bulk. Cargo (e.g. metal ores, coal, aggregates, break bulk cargo) is most often transported in open top hopper cars. They are unloaded by either a wagon tippler or slots in the wagon chassis as well as lower parts of the side walls, swinging side flaps and sliding walls.

Other wagons for transporting loose cargo (e.g. lime, fertilisers, sand, gravel, clinker, slag) have separate tanks (tank wagons divided by compartments), which are unloaded by chutes in the chassis by means of compressed air injection (it loosens the cargo and pushes it out through pipes).

Sea and river transport (sea bulk carriers, river barges) (Christowa, Dobrowolska, 2011) is widely used for transport of loose cargo. However, it requires special precautions. Remember, for example, that the smaller and lighter the load, the more likely it is to shift around. Grain can be an example of cargo which during the ship's swinging moves from side to side. Therefore, it is necessary to ensure that the cargo compartment is fully filled and to provide full protection, partitions should also be used. During transport by bulk carriers, it is often necessary to install a ventilation system to ensure appropriate hygroscopic conditions for the transported goods. 
When transporting loose cargo, packing of cargo tightly in bags is also used, which are placed in piles filling the hold tightly (everything depends on the type of hold on the bulk carrier). Loading of loose cargo on the ship is usually done through the loading chute in the sea terminal, e.g. from grain elevators directly to the ship's hold or to closed tanks on the river barge (e.g. cement).

In road transport of dry bulk cargo, e.g. flour, fodder etc., silos for transport of cargo (single or multi-chamber) are used. A chute hopper and a hydraulic lift are used to unload tanks in silos. They are most often used to blow the tank with compressed air from a compressor or these silos can be unloaded by gravity force.

For heavier materials, e.g. coal, gravel, sand, grain, etc., vehicles with rear or side-loading hopper bodies are used such as road vehicles with semi-trailers with movable floors, tipper trucks and tarpaulins (in the case of packed material).

A frequently used method of bulk handling of loose cargo is reloading with the use of cranes, port conveyors, wheel loaders, self-propelled feeder loaders, ship loaders, caterpillar cranes, self-propelled conveyors or mobile telescopic conveyors. These devices enable the transhipment of bulk cargo onto wagons, ships, barges or rolling stock.

Most loose cargoes are sensitive to weather conditions and other factors of transport. Various substances are susceptible to e.g. spillage, lumping, heating, liquefaction, spraying, etc. It is crucial to assure them proper transport conditions as well as cleanliness of the cargo space.

When transporting loose cargo it is crucial to remember about the danger of lumping together which then makes it difficult to reload them (Korzeniowski, Skrzypek, Szyszka, 2001). Therefore, care must be taken to protect against moisture, the growth of mould, microorganisms and fungi and the mixing of different varieties. In many cases, a sanitary inspection of the means of transport (e.g. during the transport of grain) must be carried out before loading.

Due to the possibility of heating of some substances (e.g. metal ores, coal) it is necessary to systematically control the temperature in the ship's hold, measure the concentration of oxygen, carbon monoxide and methane and trim the cargo to the highest possible level.

Coal also freezes when transported over long distances. In order to counteract this, it should be filled with slaked lime, calcium chloride or turf dust.

In the transport of loose cargo, the customer must be sure that the goods entrusted to the transport company reach their destination without obstacles and on time (regardless of the means of transport used). For this to happen, it is essential to use the offers of companies that have only proven and fully safe equipment and highly qualified staff.

The carrier, however, should remember about the different properties of individual substances and during their transport must be fully aware of the height of the load, its grain size and humidity to prevent lumping, spraying, going stale, crushing or even self-ignition. 


\section{IT support for transport, intelligent systems}

\subsection{IT support for logistics companies}

The observations indicate that there are three main types of IT systems supporting logistics in enterprises (Rutkowski, 2012). These are:

1. ERP systems (more than 50\% of large enterprises used this solution in 2010),

2. SCM-type systems - implemented more and more often,

3. WMS systems supporting material management.

Research shows that in the years 2009-2010 the popularity of ERP and SCM systems increased in all enterprises regardless of size.

Successfully implemented IT system enables to obtain measurable benefits resulting from the harmonisation of information within an enterprise and the receipt of that information in the same form by all users.

On the other hand, RFID is a modern technology that effectively supports the logistic information system. It is a stable technology with proven business benefits. It should be taken into account wherever it is relevant to increase efficiency, reduce losses or improve service.

It is worth noting that IT solutions used in logistics face a number of challenges e.g. setting commonly accepted standards, ensuring an appropriate level of security in relations between individual entities in the supply chain, using decision support systems, including simulation tools, information management, as well as ensuring business continuity in case of complex chains.

TRANSPORTER system is a tool that fully supports the work of the transport company's dispatcher. It enables storing data necessary for the proper functioning of the company and efficient performance of various operations on them. These data also constitute the knowledge used to fulfil the priority role played by the system i.e. the management of logistic processes. The coordination of these processes, however, does not take place with the exclusive participation of the programme which is a tool to facilitate appropriate decisions and actions by the system user. The assumptions made in the process of building the application have been fulfilled to a satisfactory degree. A built-in system can certainly be recommended for practical use in a small to medium sized transport company. It is very simple to use, so the user working with it does not need to have high qualifications. Decisions that the system helps to make will be particularly valuable for inexperienced dispatchers and will help them to gain professional experience. An additional advantage is a clear and intuitive graphical interface, equipped with a number of hints. Working with the program is therefore easy and the expertise provided is reliable. 


\subsection{Internet technologies}

Internet technology provides a very fast flow of information and unlimited range. In this way, the Internet is used not only for advertising purposes, but also for the flow of material goods, supporting the logistics processes of companies (Ciesielski, 2006).

In logistics, the Internet is used primarily for electronic data exchange (EDI), but also in procurement logistics for order processing or purchases on online exchanges, in transport logistics, e.g. tracking systems, freight exchanges, distribution logistics for the sale of goods.

EDI, as is well known, is the electronic exchange of commercial or administrative data between different computer systems, using an agreed formatting standard. If EDI is used, instead of paper documents sent by post (e.g. order, order confirmation, invoice), the equivalents of these documents are transferred in the form of computer files. Files are sent electronically to the addressee's computer system and then processed by an application interpreting the received data structures. The use of electronic data exchange reduces costs, eliminates errors during data entry and, which is not insignificant at present, eliminates language barriers. It also allows for fast data transfer and processing, and thus improves the organisation and circulation of information, reduces inventory and improves the competitiveness of the company.

Due to the open nature of the Internet, the transmitted documents are exposed to many dangers. Several types of EDI are used in online communication solutions for EDI. For instance, Mail-based EDI with the use of e-mail, WEB-EDI with the use of WWW pages, http protocol and SSL and XML-EDI data encryption protocol with the use of a new language to describe XML documents.

Today, modern technologies are becoming available not only for large companies, but also for small and medium-sized enterprises. For companies that have not yet used EDI, the processing scheme using XML is simplified because it does not involve the translation of EDI messages. The costs of implementing such a system are much lower than those of traditional EDI. This is due to the ease of access to the Internet and low software costs.

In the case of order processing, an important component of the delivery time is the time needed to process the order. It is possible to send and receive orders faster via e-mail than a letter sent using the traditional method. It is also feasible, unlike fax machines, to send various types of information in the form of computer files (spreadsheets, word files, graphic files, databases) which can be processed. The data delivered in this way is of very good quality and the use of e-mail itself contributes to the reduction of costs of business activity. Unfortunately, there are some risks associated with the use of e-mail, such as the low reliability of the signature and the need to print orders.

It is very common to use a web browser in order logistics as a tool for placing orders in virtual shops. Thanks to the use of such a technique, the order processing is significantly simplified and automated, and the order processing time is very short. 


\subsection{Online freight exchanges}

On the other hand, online freight exchanges are platforms for establishing business contacts between companies in the B2B (Business-to-Business) sector.

Freight exchanges may be global or local. At present, large companies are the most interested in virtual markets as they can significantly reduce the costs of supply of materials for production. By being able to negotiate with thousands of suppliers offering their goods on the online freight exchange, you can get low prices in a relatively short time (Buchalski, 2009). It can be assumed that the online freight exchanges will have a profound impact on the production process and distribution system. Online freight exchanges reduce the cost of finding new suppliers and customers and speed up the flow of information. They promote efficient ways of doing business. Online freight exchanges are a kind of "auctions" of inquiries, orders for goods and the sharing of logistics. They promote efficient ways of doing business.

Retailers, wholesale distributors and suppliers participating in online exchanges save on transaction costs. They can make smaller inventories and optimise resource utilisation and eliminate some of the losses in the value chain.

In the case of transport logistics, the Internet offers freight exchanges and a tracking system. Online logistics exchanges are websites that offer supply and demand for logistics services, such as available transport services. The use of such exchanges brings many benefits to companies, such as reducing empty miles and the resulting cost savings. Companies can optimise their transport routes and increase the number of orders thanks to the exchanges. In Europe, one of the most thriving online freight and vehicle exchanges is DAT Services. There are also several freight exchanges in Poland (Sosnowski, Nowakowski, 2015).

The tracking system is a complementary service for the transport of goods used by modern logistics companies. Its aim is to increase the level of customer service through the use of new technology (GPS system, e-mail, web pages and WAP). The tracking system operates by assigning an individual number to each load. The number can be read by a scanner connected to a GSM mobile phone and sent to the control unit. Once the goods have been loaded onto the means of transport, the route is tracked using GPS. After the delivery of the goods, this fact is registered using a scanner. The sender and receiver can use a web browser, email, or mobile phone to track what is happening to the goods and estimate delivery times. The shipment number is always known to the sender, and the receiver must contact the sender to get to know it.

Distribution logistics includes the sale of tangible goods and the sale of digital products. The Internet is the distribution channel for goods sold on-line through online shops. In addition, the Internet enables the transfer of all products that are digitally recordable. This solution significantly shortens the distribution channel, thus achieving faster access to consumers and unlimited sales reach. Using this distribution channel, it is feasible to send, among others, software, newspapers, books, music to the customer. 
The Internet is an effective information carrier and an excellent distribution channel. It is also a source of new opportunities for logistics as it significantly reduces costs, shortens the time of operations and limits the number of middlemen. It is vital for logistics processes to use the Internet to exchange data and consequently lead to closer cooperation between companies at every level of the supply chain.

The establishment of online freight exchanges made searching for business partners easier and thanks to the openness of the Internet created access to them not only for large enterprises, but also for small and medium enterprises enhancing the possibilities of beneficial cooperation and constituting a new quality in business contacts which became more flexible and created at the moment of occurrence of a specific need. The development of the Internet began a new stage in the activity of transport, forwarding and logistics companies.

Using IT, online freight exchanges operate in the form of interactive platforms in the transport services market, connecting forwarding and transport companies as well as production and trade companies together. These platforms give the opportunity to place detailed information about cargo, available vehicles which can be used for transport services and information about the possibility of contact with dispatchers. Any interested party may submit a tender for available cargo area or loads.

On the Polish market there are many online freight exchanges available for carriers, forwarders and manufacturing and trade companies operating throughout Europe providing services in many languages (Sosnowski, Nowakowski, 2015). These exchanges differ from each other, but have one common principle. They offer available loads and return loads as well as available vehicles.

Online freight exchanges are used by carriers and forwarders alike. The exchange offers both groups of users an individual package of benefits. The most significant benefit is the creation of a platform for the free exchange of information between transport and forwarding companies, thanks to which, it is possible not only to commission and win orders, but also to build contacts and long-term relations in the industry.

Some exchanges create codes of ethics, user forums, peer review systems, post-trade comments and certificates of reliable carriers. Internet freight exchanges have become an important tool to facilitate the work of a freight forwarder related to the organisation of transport processes.

The functioning of online freight exchanges is an example where new technologies, in particular ICT, can contribute to improving the efficiency of transport operations.

\subsection{IT systems supporting railroad carriers}

The development of information technologies and the use of the Internet in business on a large scale have created the basis for the development of modern communication between entities related to transport processes. The availability of information and the speed with which 
it is transmitted increase the flexibility of business operators and enable them to respond more quickly to market needs.

The analysis of the existing situation showed (Szkoda, Michnej, Lorenc, 2014) that at the current moment there is no information system enabling railroad carriers in Europe to obtain information on the safe, reliable and effective way of loading and securing goods in means of transport. Therefore, it was considered a purposeful attempt to develop and implement an information system supporting the process of selecting appropriate methods of loading and securing goods in rail transport. The analysis of methods of loading and securing various groups of cargoes, taking into account the existing laws, regulations and standards, allowed to prepare a set of input data for the designed system called LOADFIX. The LOADFIX system is therefore a response to the existing market need. In 2012, in cooperation with the Cracow University of Technology, the University of Žilina and OLTIS Group, work on this system began. Most of the input data has already been collected and the database structure and system structure have been developed. The completion of the works was planned for 2015 .

\section{Final conclusions}

The following conclusions can be drawn from the considerations carried out:

1. Transport enables economic growth and job creation. The development of transport must be sustainable. As a global sector, effective actions in this area require a tight international cooperation. Transport is one of the pillars of the development of the economies of the EU Member States. The efficient functioning of transport services has a significant impact on the efficiency of management and on measurable benefits. In 2018, transport expenditure in the European Union reached EUR 1 trillion.

2. The Single European Transport Area should facilitate the movement of citizens and goods, reduce its costs and ensure the sustainable development of European transport.

3. In March 2011 The European Commission approved the implementation of a strategy (Transport 2050) for a competitive transport system that will increase mobility, remove major barriers in key areas and boost employment. At the same time, proposals were made to significantly reduce Europe's dependence on oil imports by 2050 and to reduce carbon dioxide emissions from transport by $60 \%$. Hence the subtitle "Towards a competitive and resource efficient transport system" appeared in the White Paper.

4. The White Paper on a European communication policy makes explicit reference to the right to information, freedom of expression, integration, diversity and enhanced participation that should guide EU policy-making in this field. 
5. The choice of objectives and individual values (e.g. the share of low-carbon fuels) to be achieved for these goals is certainly questionable, but implementation will nevertheless make EU transport much more energy-efficient and significantly less environmentally damaging.

6. Such a transport system will make it possible to implement the principle of sustainable development in practice. What impact will the implementation of the latest White Paper have on the Polish transport system? The answer to such a question is an open one.

7. The development of information technologies and the use of the Internet in business on a large scale have created the basis for the development of modern communication between entities related to transport processes.

8. Promoting more efficient and sustainable modes of transport, especially rail freight, has been a key element of EU policy for 25 years.

\section{References}

1. Buchalski, Z. (2009). Computer Advisory-Decision System for the Logistics Services Support. Polish Journal of Environmental Studies, 18, 3B, 53-57.

2. Christopher, M., Peck, H. (2005). Logistyka marketingowa. Warszawa: PWE.

3. Christowa. Cz., Dobrowolska, M. (2011). Polityka transportowa i jej wpływ na rozwój transportu wodnego śródlądowego w Polsce. Logistyka, 6.

4. Ciesielski, M. (2006). Logistyka w biznesie. Warszawa: PWE.

5. Domańska, A. (2006). Wptyw infrastruktury transportu na rozwój regionalny. Warszawa: PWN.

6. Engelhardt, J. (2018). Sektor kolejowy w polityce transportowej Unii Europejskiej. Etapy tworzenia jednolitego europejskiego obszaru kolejowego. Warszawa: Wyd. edu-Libri.

7. Environmental indicator report 2018 - In support to the monitoring of the Seventh Environment Action Programme, Report, 19 (2018). Luxembourg.

8. Grzelakowski, A., Matczak, M., Przybyłowski, A. (2011). Polityka transportowa Unii Europejskiej i jej implikacje dla systemów transportowych krajów członkowskich. Gdynia: Akademia Morska.

9. Grzelakowski, A.S. (2003). Polityka transportowa. In: Biała Księga 2003, Liberalizacja i Integracja Rynków Przemysłów Sieciowych. Trwaty Rozwój. Gdańsk-Warszawa: Polskie Forum Strategii Lizbońskiej.

10. Grzywacz, W., Wojewódzka-Król, K., Rydzkowski, W. (2006). Polityka transportowa. Gdańsk: Uniwersytet. Gdański.

11. Igliński, H. (2011). Biała Księga 2011 - implikacje dla polskiego systemu transportu. Logistyka, 4. 
12. Januła, E., Truś, T., Gutowska, Ż. (2011). Spedycja. Warszawa: Difin.

13. Korzeniowski, A., Skrzypek, M., Szyszka, G. (2001). Opakowania w systemach logistycznych. Poznań: WSL.

14. Mendyk, E. (2009). Ekonomika transportu. Poznań: Wydawnictwo Wyższej Szkoły Logistyki.

15. Pieriegud, J. (2015). System transportowy Polski. 10 lat w Unii Europejskiej. Warszawa: Oficyna SGH.

16. Pikuła, Ł.J. (2015). Aksjologia Unii Europejskiej w świetle źródeł, wykładni i instytucji. Toruń: Wyd. Adam Marszałek.

17. Pisz, I., Łapunka, I. (2013). Systemy transportowe wspomagające realizację projektów logistycznych w branży transport-spedycja-logistyka. Logistyka, 5.

18. Przybyłowski, A. (2004). Wpływ polityki transportowej i regionalnej Unii Europejskiej na rozwój infrastruktury transportowej $w$ Polsce. Rozprawa doktorska pod promocją A.S. Grzelakowski. Gdańsk.

19. Rutkowski, L. (2012). Metody i techniki sztucznej inteligencji. Warszawa: PWN.

20. Rydzkowski, W., Wojewódzka-Król, K. (ed.) (2008). Transport. Aktualne problemy integracji UE. Warszawa.

21. Sikorski, P., Zembrzycki, T. Spedycja w praktyce. Polskie Wydawnictwo Transportowe.

22. Sosnowski, J., Nowakowski, Ł. (ed.) (2015). Elektroniczne giełdy transportowe. Warszawa: Difin.

23. Szkoda, M., Michnej, M., Lorenc, A. (2014). Wspomaganie informatyczne procesów ładunkowych w transporcie kolejowym. Logistyka, 2. 